Hanging Tree as a Place of Memories - Encounters at a 1916 Execution Site

Janne Ikäheimo,

University of Oulu, Archaeology

P.O. Box 1000, 90014

Finland

$+35850-3503173$

janne.ikaheimo@oulu.fi

Tiina Äikäs

University of Oulu, Archaeology

P.O. Box 1000, 90014

Finland

$+35840-5887131$

tiina.aikas@oulu.fi

\title{
Note on Contributors
}

Janne Ikäheimo is a Lecturer in archaeology at the University of Oulu. While his dissertation focused on (2003) ceramic cooking pots produced in Roman Africa, his current research interests include "neo-relics" in contemporary society, the early Medieval period in Northern Finland and the 
use of native copper in eastern Fennoscandia and northwest Russia during the Neolithic. Janne is principal investigator of the research project "The use of materials and the Neolithisation of NorthEastern Europe (c 6000-1000 BC)" funded by the Academy of Finland (2013-2017).

Tiina Äikäs is a post-doctoral researcher funded by the Academy of Finland working in Archaeology at the University of Oulu. Her dissertation (2011) focused on the landscape analyses and site biographies of Sámi offering sites, including their use from Iron Age to present. Tiina's research interests include contemporary archaeology, ritual archaeology, and the use of interviews in archaeological research. She is interested in the meanings of cultural heritage in the contemporary world.

\begin{abstract}
Near the city centre of Oulu in northern Finland, one comes across a peculiar monument: a pine tree turned into a memorial that marks the site of the last official execution by hanging in the country. Archaeological excavations took place at the hanging site in August 2014, not only to gather archaeological evidence on the history and use of the memorial, but also in order to offer people a way to share their memories and recollections of this rather unusual place. In this article we discuss the data gained from interviews $(\mathrm{N}=20)$ conducted in connection with the excavations. The interpretation of the data shows that the hanging tree memorial has been and continues to be a place of both private and communal memories. It has been used for private gatherings and visits as well as for nationalistic purposes. The authenticity of this site as the actual place of hanging can be reasonably questioned, but the place is still important for local people.
\end{abstract}

Keywords: Dark heritage, memories, nation building, execution site, Finland, Taavetti Lukkarinen, $65^{\circ} 00^{\prime} 32.9^{\prime \prime} \mathrm{N} 25^{\circ} 30 ' 36.6^{\prime \prime} \mathrm{E}$ 


\section{Hanging Tree as a Place of Memories - Encounters at a 1916 Execution Site}

\section{Introduction}

Since its early days, archaeology has been used for nationalistic purposes and archaeological finds and interpretations have been a vehicle for nation building (Kohl and Fawcett 1995; Díaz-Andreau and Champion 1996; Fewster 2006; Núñez 2011). The uses of archaeology have varied, from manipulating archaeological data in creation of invented pasts, to positive use of archaeology to create a sense of togetherness and to resist colonialism and racism (Trigger 1995, 277; Kohl 1998). However, archaeology and confrontations with material culture also possess the power to initiate a process of remembering. The method is especially useful for evoking dark memories, which people are keener to forget than to remember (Hallam and Hockey 2001; Burström 2009a; Burström et al. 2009).

Thus, when we investigated the surroundings of a memorial erected at a 1916 execution site located in Kontinkangas (Oulu, Finland) in August 2014, we used the archaeological performance known formally as archaeological excavations as an arena for the local people to approach the researchers and share their memories and recollections about the site. Several newspapers informed those potentially interested with a news item published prior to the excavations, indicating that archaeologists would like to hear their stories about the place.

The week-long excavations, explored an area of $11.5 \mathrm{~m}^{2}$ within and around the hanging tree memorial, and mapped the surroundings of the monument (see Ikäheimo et al. in press). The team also interviewed the people who had decided to visit the excavation and others who contacted Äikäs via e-mail or phone after reading about the excavations. We felt the interviews could provide an alternative way of enquiry that could potentially reveal the meanings and memories related to the 
hanging tree memorial and hence help us to understand its role as a place of memories and cultural heritage. Somewhat surprisingly, the excavations and related interviews also offered the interviewees an opportunity to deal with dark family histories and seek consolation. When people started to show up at the site, we avoided mentioning that due to results of prior archival research, this was probably not the original hanging place. We decided this in order to gain information on how people experienced the place without knowing whether it was 'authentic' or not. As the work progressed, we made new information about the site available to the audience, and both the archaeological excavations and the unearthed archaeological material served to awaken memories and to create an arena for meeting people and collecting stories. This evidently had an impact on the way some people experienced the place, while the investigators themselves had to contemplate, whether or not the excavations had given a new meaning to the place or deprived the site of its previous significance.

The team conducted 20 interviews variously by phone, e-mail or face-to-face. Only three people spontaneously established contact after reading the news item release released prior to the excavations and wanted to share their stories on the phone. One of them also visited the site later on. Three other people, who were not residents of Oulu, shared their stories by e-mail after fieldwork. The majority of the interviews took place, however, during excavations at the site, which helped to trigger additional memories for some participants. The interviews were semi-structured and informal. We also audio recorded three interviews, with most interviews consisting of short remarks made by the visitors followed by further defining questions from us. Most of the visitors seemed uncomfortable with a formal interview arrangement requiring tape recorders and consent forms, hence we presented them with a consent form but told them that they can also give their consent orally (this complies with the ethical guidelines of the Finnish National Board on Research Integrity $\left.[\mathrm{TENK}]^{\mathrm{i}}\right)$. We therefore informed all interviewees that they would be participating in our research and asked whether they would like to answer anonymously or with their name. 
The excavations and the interviews indicated that the presumed site of the execution has had, and continues to have, considerable relevance for the public as well as individuals. The site is also a good example of how a dark heritage site - a site associated with death and suffering, modern military conflict, mass violence or atrocities (e.g. Stone 2006; Logan and Reeves 2009; Seitsonen 2018) - can be reprogrammed through memorialization into a vehicle for building national pride (e.g. Clarke et al. 2017). The site is also an illustrative example on the importance of a place regardless of its authenticity - for personal memories and memorialization. The cultural geographer Pauli Tapani Karjalainen $(2004,2006)$ coined the term 'topobiography' to describe how places connect to individual life histories and to identity, as places and memories of them are crucial for personal identity building. According to him, memories help us to remember the important events in our lives that happened in certain places. Over the course of a century, the hanging tree memorial has had assigned to it with various meanings so that it ended up becoming relevant for different individuals and groups in different ways. First, however, it is necessary to offer a concise site biography to contextualize subsequent observations.

\section{A concise site biography}

The story of the site begins when Russian gendarmes hanged a Finnish man named Taavetti Lukkarinen (Fig. 1) on 3 October 1916. By that time, the predecessor of the modern sovereign state of Finland was an autonomous Grand Duchy under Russian dominion, and Lukkarinen was sentenced to death for high treason under Czarist Russian martial law, as he had assisted the failed escape attempt of three German prisoners of wars from the Murmansk railroad labour camp on Boxing Day 1915. As he had been able to escape from the scene of the crime to Sweden (Fig. 2), from where he attempted to return longing for his wife and two children, he was arrested without resistance on 6 June 1916 near Oulu. 
After four months of incarceration in the Oulu County prison (Fig. 3), just after midnight on 3 October 1916, Lukkarinen was escorted to the execution site in Kontinkangas by some forty Russian gendarmes, two Finnish mounted police officers and a prison priest named Arvi Järventaus. After execution, which was the last official hanging in Finland, Lukkarinen's body was buried by the hanging tree. As the townspeople saw this act as extremely disrespectful, his body was exhumed and reburied to the Oulu Main Cemetery the following summer, after the February Revolution of Russia (Wegelius 1924, 58-59; Lackman 2012, 129).

After the execution, but before reburial, the townspeople developed a custom of visiting the hanging site mainly on Sundays. Reportedly, as they started to carve crosses into the two pines that were used as vertical supports of the crossbeam in hanging (Manninen 1939,96), the trees were soon cut down by the Russian authorities. Furthermore, the pine that now forms the epicenter of the memorial is said to be located circa twenty meters west of the original hanging site (Manninen $1939,96)$ implying that the authentic hanging site was destroyed when the Oulu University of Applied Sciences constructed a new wing for its School of Health and Social Care (Fig. 4) in 20102012. Ironically, the salvage of an authentic memorial but inauthentic hanging tree from the construction works was hailed by the regional newspaper Kaleva as an exemplary act of local cultural heritage preservation.

The memorial, which the Union of Finnish Civil War Veterans (an extreme right-wing movement) established in 1935 , is composed of a pine tree encircled by a red granite round base topped by a wrought iron rail. The rail divided into three horizontal zones is painted black and decorated with Lutheran crosses. A commemorative inscription on a copper sheath covering the top of the handrail (Fig. 5) states in rather pathetic tone (our translation):

From this tree was hanged and in a pit beneath it activist Taavetti Lukkarinen was buried by the authorities of the Russian tyranny on 6 October $1916^{\mathrm{ii}}$. From here his dead body was taken to the hallowed soils of the Oulu Cemetery in 1917. May the terrifying memory of this 
event pass to generations to come, and evoke abhorrence towards foreign terror, and may it raise courage and strength in the nation to live and die for the independence and freedom of the fatherland.

The symbolism embedded in the memorial resonates with the inscription. Granite is the national rock of Finland and customarily used for hinting at virtues like endurance and stability that the Finnish people greatly appreciate. The rail refers to the same virtues in metal, reminiscent of a churchyard fence and, in a way, consecrating the site of a hideous deed. The decorative crosses on the rail further underline that Lutheran values are quite different from those of the Orthodox Christian 'savages' responsible for the hanging.

Both local newspapers, Kaleva and Kaiku, extensively reported on the festivities related to the memorial's inauguration on 6 October $1935^{\mathrm{iii}}$, while they had been forced to remain silent about the execution in 1916 due to Russian war censorship. These reports focused on the tragic fate of Taavetti Lukkarinen by reproducing the eyewitness account of prison priest Järventaus, while also noting the ceremonies performed at the site and the presence of Lukkarinen's widow and their children. The newspaper reports also mentioned that the mayor Heikki Karjalainen - an active member of the Union of Finnish Civil War Veterans himself - promised that Oulu City Board would accept the maintenance of the site (Kaleva 1935), a point on which the board meeting unanimously agreed upon the day following the inauguration.

The memorial's inauguration was a somewhat isolated act, as the site seems otherwise to disappear from official attention. For example, its location was marked for the first time onto a base map published by the National Land Survey of Finland in 1981, its fourth edition, while the first edition had been already published in 1953. Nor does the site enjoy protection through the Antiquities Act of Finland (295/1963), and it is therefore absent from various online site registries maintained by the Finnish Heritage Agency. The status of the site is surprisingly similar on a local scale. On the official city plan, the area surrounding the memorial is marked with a 'trees to be 
saved' symbol without any explicit reference to the special status of the hanging tree. However, it is a common misconception among both the city officials and the residents of Oulu that a local statute or a national law protects the memorial. In fact, the unprotected status of the site came as a surprise to us, too.

However, as sites of historical importance often do, Taavetti Lukkarinen's memorial has also posed an obstacle to urban development. The main entrance of the Oulu University of Applied Sciences main building is located diagonally behind the small pine grove left for the sake of preserving the memorial. One can therefore only access the entrance through walkways located next to the buildings surrounding the pine grove, and currently no visual point of focus to the main door exists (Fig. 6). Thus, the side of the building complex that should form its flagship entrance resembles a backyard and many visitors have a hard time understanding the right way to enter the building and its offices. The Oulu University of Applied Sciences has pre-drawn plans for developing the pine grove into a more visitor-friendly experience. This involves installing a raised plank walkway through the grove to the main entrance of the school with a bypath leading to the memorial. A platform with an explanatory signboard by the memorial and lighting system for nightly illumination would make it even more accessible (I20, 2014). However, the city of Oulu has rejected these plans and treats the memorial as a protected site, while it is not officially protected at all.

The situation might change in the near future, as our intention is to assist the Oulu University of Applied Sciences in their pursuit to develop the pine grove in a way that will not pose a threat to the memorial's integrity. The second section of the Antiquities Act concerning the definition of ancient monuments states that stones, crosses, statues, and other similar memorials that have been erected to memorialize an individual or an event, or for religious purposes, are also legally protected. Therefore, the memorial should probably be included in the Ancient Monument registry and we will propose this to the Finnish Heritage Agency soon. This involvement in the 
site's protection and development has been based exclusively on our research interests and work as professional archaeologists at the University of Oulu, and the co-operation with the Oulu University of Applied Sciences has been conducted informally.

\section{Creating and interacting with the place of national pride}

While the site gained local significance immediately after the execution, based on the immediate response of the townspeople, only the inauguration of the memorial by the Union of Finnish Civil War Veterans in 1935 deliberately aimed to raise national pride at a time of tense international power politics that ultimately escalated to the Second World War. From this perspective, the hanging site was a perfect vehicle for anti-Soviet propaganda (Lackman 2012, 129), which was in high demand due to increasing diplomatic pressure and territorial claims to Finland that the Soviet Union put forward. Here a place of earlier events and memories acquired new meanings and became charged with new emotions when new distressing events occurred (Smith-Solbakken and Weihe 2012, 196). It was not the only memorial created for this purpose in the Oulu region; the following year a memorial was erected in the village of Vesala, Ylikiiminki in honour of Pekka Vesainen, the epic $16^{\text {th }}$-century guerilla warlord famed for his devastating raids of Russian Karelia (Enbuske 2013, 37).

The interviews also gave evidence on active use of the Taavetti Lukkarinen memorial for nationalistic purposes in peacetime. The Finnish Defense Forces had one of its garrisons located next to the town just a kilometer north-northwest from the hanging site, which formed the last stop of a three-part itinerary including the County prison and County asylum located also near the garrison (Fig. 3). The new recruits were first shown the two places where they would be end up in case of mental or physical misbehaviour, while the hanging tree was used as evidence of what would happen to them, if the country they were about to be trained to fight for was overtaken by foreign armed forces (I5 Karhumaa 2014). The tradition, taking place three times a year, started in 
the 1960s and was discontinued only after the closure the Oulu garrison in 1998. In addition, one of the interviewees mentioned that while participating in military exercises taking place in the Kontinkangas area during his military service in the late 1950's, he and his brothers-in-arms had wondered about the tree memorial during the breaks but neither them nor their officers had any knowledge regarding the story behind it (I3 2014).

Besides being a place suited for recruit motivation, the memorial has also served as the locus of small-scale festivities for various veteran associations, especially in the 1950s and 1960s. Today, as the number of Finns who have fought in wars while defending their homeland has diminished to ca. 30000 people with an average age of 90, such gatherings do not take place at the site anymore. Nevertheless, the military-related interaction with the memorial continues even today, but its nature has changed to the site maintenance. The Guild of Artillerymen in Northern Finland cleans up the surroundings of the memorial in an annual event as voluntary work. Another organization involved in the upkeep of the memorial is the Oulu chapter of the Lions Club International that paid for the restoration of the copper sheath covering the handrail of the iron rail (I13 2014). As mentioned above, the Oulu City Board accepted the responsibility for the maintenance of the monument, but has ever since neglected the task, resulting in this type of self-motivated community initiative.

\section{A place for personal memories}

Places of conflict or of personal trauma can evoke strong emotions and different perceptions depending on the emotional attachments of the individuals to these places (Schofield et al. 2002, 4). The majority of interviewees who shared their recollections of the site with us did so for the personal memories of the site, but only for three did the place have an unusually intimate meaning. Marianne Lukkarinen, whose great grandfather was Taavetti Lukkarinen, had established contact before the excavation and told us that the story had been passed on from generation to generation in the Lukkarinen family. From their point of view, the death sentence was greatly unjust as the 
Russian officials had cruelly exploited the case to set an example for those about to assist the fifth column. Marianne Lukkarinen had visited the memorial as a child but not in adulthood as, from her point of view, the hanging tree was oppressive; she wanted to find and visit it again but had not previously have the nerve to do it. She had instead visited and brought a candle to the grave of her great grandfather at the Oulu Main Cemetery (I2 Lukkarinen 2014).

Nevertheless, during the excavations Marianne Lukkarinen decided to visit the hanging site; an event that seemed to cause her both anxiety and relief. The prevailing feeling, however, seemed to be joy at the fact that her great grandfather's story had raised interest and that it would be highlighted again, perhaps this time from a different perspective. Dimitrovski et al. (2017) have observed that family bonding is an important factor in relation to visiting sites with dark attributes. The family members and friends of a victim visit these sites often to feel a sense of belonging and to demonstrate their commitment to the victims, and they are more emotionally involved than other visitors (Dimitrovski et al. 2017).

Some have argued that in cases where the relatives find it hard to visit a place of dark memories, an organized commemoration can motivate them to pay a visit to the site (e.g. Dimitrovski et al. 2017). On 3 October 2016, when exactly a century had passed from Lukkarinen's death, Ikäheimo together with Marianne Lukkarinen organized a commemorative event. It commenced at midnight at the Oulu County prison with an introduction to the last moments of Taavetti Lukkarinen and continued to the hanging tree memorial with the reading of written accounts of Lukkarinen's death, and with Ikäheimo explaining the results of the archaeological investigations.

Finally, a group of some 30 attendees - among them four of Lukkarinen's five great grandchildren- proceeded to the cemetery with lanterns lighting the way in the dark winter night. The attendees placed the lanterns by Lukkarinen's grave where Marianne Lukkarinen described the 
meaning of Taavetti's story for the family. She remarked that the story of Taavetti has been used both as a deterrent and as an example of bravery - but while Taavetti Lukkarinen had become a myth, the real person behind the myth was largely forgotten. A glimpse of the person behind the myth was offered through an e-mail interview with another family member, the son-in-law of Taavetti Lukkarinen's brother, 80-year-old Antti Pasanen who remembered his discussions with Ellen, the daughter of Taavetti Lukkarinen. According to him, 'Ellen reminisced that the best memory about her father Taavetti was from the last summer in 1915, when he built a playhouse at home in Pajusaari even though his hand was sore' (I17 Pasanen 2014).

Pasanen and his wife had visited both the hanging tree and the grave on several occasions. He also found it important to share knowledge about Taavetti Lukkarinen's story to future generations, and had used it as a bedtime story. He described the execution as an incredible and shocking deed - a sort of a judicial murder. On the other hand, he pointed out that the story of Taavetti Lukkarinen had not always been publicly discussed due to the political atmosphere (I17 Pasanen 2014). During the Cold War, Finland had to be careful regarding its relations with the Soviet Union and in the late 1960s, when the left-wing parties were at their strongest, this would have been particularly unwise.

Passing the knowledge of both the place and the events associated with it had also been important for non-family members. The former senior lieutenant of the Finnish Defense Forces, Jorma Karhumaa, told us that he had shown both the hanging tree and the burial place of Taavetti Lukkarinen to residents and had also taken friends who were visiting him to these sites (I5 Karhumaa 2014). In his report to the authors Karhumaa states: 'All have not forgotten Taavetti!' Local schools have also played a part in passing the story of Taavetti to future generations. One interviewee mentioned how a teacher had told a scary story about the place and this had piqued her interest (I12 2014), while another had heard about the place in school and had then visited the place with his own children after they had also heard the story in school (I7 2014). The story of Taavetti 
Lukkarinen and the strong emotions that the place raised had affected one interviewee so much (I1 2014) that she named her son Taavetti.

The descendant of the other Finnish mounted police officer obliged to witness the hanging volunteered a completely different view on the story of Taavetti Lukkarinen. The interviewee started the e-mail he sent to Äikäs by stating: 'The past is haunting me as it did my family in my childhood.' The interviewee told us that his family had never discussed his relative's life, and only archival research done as an adult had led to more profound knowledge about the officer's life. The participation of a relative in the execution of Taavetti Lukkarinen was a silenced and shamed part of the family history that had shadowed the life of older family members and even the life of the interviewee (I19 2015), although as a police officer, the ancestor had been on duty with no possibility of disobeying the order.

Here, national shame is tied to the history of hurt individuals - hence the personal has also political dimensions (Logan and Reeves 2009). In the bigger picture, blame for their participation in the execution of Taavetti Lukkarinen has fallen on all Finnish officials (except the prison priest Arvi Järventaus) involved in the execution of Taavetti Lukkarinen. When Aaro Lindqvist, the chief of the Oulu police at the time of the execution, took his own life just a few years after the incident, it was seen as act of reconciliation for his passiveness in the case (Pentzin 1943, 78).

For other interviewees the hanging tree memorial had more mundane meanings. It formed a visual backdrop for childhood plays (I8 2014 and I14 2014) or skiing trips (I12 2014). In such associations, the place did not always raise any special feelings, but was rather a part of daily life. 'As kids we didn't appreciate it,' comments one interviewee (I8 2014) hence referring to a later change in the appreciation of the place. As the area surrounding the memorial has undergone very rapid urban development in the past few decades, the question regarding the actual hanging tree's exact location raised strong emotions in several interviewees. The clash between the new reality and 
old mental images was quite dramatic and when the insecurity was increased by an opposing opinion presented by another visitor, a quarrel between two interviewees escalated almost into a fight (I6 2014). From our point of view, such an emotional attitude towards the location of the hanging tree and even the memorial represents an interesting example of how places and the changes they undergo can be remembered and interpreted differently. Some interviewees had a recollection of a lonely tree standing on heathland; others had been able to locate the place thanks to landmarks like roads or barns. Nevertheless, all the interviewees as well as ourselves noted the radical change that the construction of the Oulu University of Applied Sciences main building had caused.

\section{Place of emotions - source of inspirations}

The hanging tree and its surroundings were long located outside the urban development of Oulu. For example, Kaleva reported how on 27 July 1908 the local police had raided the woods of Intiö and Kontinkangas and had arrested three vagabonds in addition to scaring away several individuals involved in illegal gambling. One of the interviewees stated that the area of Kontinkangas was actively used for the latter purpose even in the 1950s (I6 2014) as it was remote but still well connected to the town through a main road leading from Oulu to Kajaani on the northern edge of the area. Another interviewee informed us that as late as in the 1990s, before the construction spree of the Oulu University of Applied Sciences, local drinkers had patronized the area under the tree (I7 2014).

In fact, a way of interaction with the memorial totally absent except in the former statement from public feedback, but very evident in the archaeological data gathered from the site, was its suitability for intoxicated ponderings of questions related to life and death. In other words, the assemblage was dominated by finds related to the consumption of various alcoholic beverages, such as bottle glass and beer bottle caps - while a solitary fragment of a small glass syringe may even 
denote the use of harder substances at the site. A few pieces of clear plastic from a compact cassette case show that the visits to the site may have been further enhanced with music played from battery operated portable cassette players and influenced by Gothic horror. The hanging tree memorial of Taavetti Lukkarinen might thus raise similar reflections to the "car cemetery" in southern Sweden containing some 150 car wrecks from the 1930s-1970s, which has gained relevance as an unofficial cultural heritage site for people visiting it. Mats Burström (2009b) states that the site with cars in a state of decay offer people an opportunity to ruminate on the passing of time, past and present, and so on.

The location of the hanging tree on the former outskirts of the town as well as the events that took place there in 1916 constitute its indeterminate and liminal nature. It was a place where unresolved issues came across as a haunting and the material culture carried memories of injustice (cf. Cameron 2008; Herva 2014). Although the body of Taavetti Lukkarinen was exhumed and reburied in Oulu Cemetery soon after the execution, his restless soul was probably believed to be attached to his place of death.

A peculiar archaeological find, a magic deposit deliberately hidden in the base of the memorial (see Ikäheimo et al. 2016) indicates that the hanging tree was experienced, at least by some, as a scary place to the point that material measures had to be taken to actively reduce the threat it might pose to the living. On the other hand, there are also some accounts of sightings of the ghost of Taavetti Lukkarinen (Silvander 2005, 5). This is not a great surprise, as the town of Oulu is reportedly the ghost capital of Finland where city-run guided ghost walks are extremely popular. One interviewee stated that it could be possible to sense the energy around the tree and "someone should guide the wandering spirit away so that it could find the path to the afterlife." (I18 2014)

Despite these otherworldly qualities, the hanging tree has turned into an urban legend especially for many young Oulu residents; people are aware of both its existence and its 
approximate location, but the story behind the memorial has largely been forgotten. Some even think that the definition 'hanging tree' is based only on a myth. This can be also true for people who are in 'contact' with the tree and the memorial on daily basis: the students and teachers of the Oulu University of Applied Sciences. Only a few of them dared to visit our excavations even though they had to pass by on their way to classes. The opinion of a student (I11 2014) available for an interview was that in general the students know nothing of the place. The lack of knowledge can be partly explained by a lack of visual connection, while the very limited information offered at the site - the inscription on the handrail actually raises more questions than it answers - is another factor contributing to the obscurity of the memorial.

On the other hand, modernity and changing trends and ever-improving means of communication have set the site into a new context, as it today forms a backdrop to a novel form of play or sport. Geocaching's rapidly growing popularity has introduced a novel way of interaction with the memorial. At first, the cache was a small plastic box hidden into the memorial itself, but today it has been transformed into a microcache concealed by a dead branch of a young tree growing nearby. To find the cache, one must first locate the memorial, which is not necessarily an easy task due to surrounding buildings. Nevertheless, the cache keeps attracting one to four daily visitors to the site and quite many of these visitors have made a comment about the memorial on the webpage that contains clues for finding it. Geocaching hence offers a new way for people to interact with and experience cultural heritage (see Seitsonen 2018: 159).

The memory and the memorial of Taavetti Lukkarinen have also been a source of artistic inspiration, and literature is the most apparent form of self-expression to draw inspiration from the tragic events. The execution has inspired novels and various written dramatizations, while poems addressing the tragic hero himself are not lacking. Of these contributions, the most well-known literary work is probably the novel "Isäni, sankari" (My father, a hero) published in 1987 by an established novelist Joni Skiftesvik (b. 1948). Skiftesvik had originally intended to write a heroic 
biography of Taavetti Lukkarinen, but due to the lack of heroic aspects in his story, he decided to write a story about a fictitious character named Taavetti Vakkuri whose fate was in many ways similar to Lukkarinen's. The novel was later turned into a play, which premiered in the Jyväskylä City Theatre in 1989.

Artistic presentations can also shape political conceptions. For example, a group of Sámi artists called Suohpanterror uses their art to take a stand on ethno-politics criticizing, amongst other things, the fact that the Finnish government has not agreed to sign the ILO 169 convention (Hautala-Hirvioja 2015; cf. Edelman 1995) guarantee the rights of indigenous and tribal peoples. Similarly, the fate of Taavetti Lukkarinen and his memorial have been a source of inspiration for a modern dance performance entitled 'Rules' completed in 2003. According to the artists, the performance sought to explore various consciously or subconsciously followed rules that regulate our lives (http://www.kaleva.fi/uutiset/kulttuuri/liikkeelle-taavetin-hirttopuusta/490645/).

\section{Discussion}

The hanging place of Taavetti Lukkarinen and its memorial highlights how the meanings given to a place and in this case to cultural heritage - even to one without official status - can change over time and connect to individual life histories. The memorial arose from nationalistic interpretations of the past, and the inscription on the rail surrounding the tree as well as the symbolic meanings of the materials and motives chosen for the memorial highlight how the construction of the site served nationalistic purposes. Lukkarinen was depicted both as an activist of the Finnish Jäger Movement and a heroic martyr fighting against tyrannical Russian administration, and the eyewitness accounts were adjusted accordingly to create a story about a hero. While the site's later use by the military emphasizes this 'official' nationalistic role, this imagining of Taavetti Lukkarinen as a patriot has also influenced the personal memories of his descendants. 
The remembrance of Taavetti Lukkarinen may be a political act (cf. Heimo and Peltonen 2003), as political allegiance defines who should and can be remembered. The memory of Lukkarinen was and is enforced for nationalistic purposes, but on the other hand, family members were silenced when the dominant left-wing politics made him an unwelcome topic of conversation. Hence, political memories can have both individual and broader social dimensions. Memories are an expression of social and political power and can be linked to national identity and ideologies.

Occasionally, either intentionally or unintentionally, collective memories take a distorted form to reinforce national identity. For example, the Germans stationed in Finland during the Second World War are remembered less as 'brothers in arms' than as 'Nazis who burned Lapland'; in the Moscow Armistice signed with the Soviet Union in September 1944, and Finland was assigned the task of expelling the German troops from its territory. This resulted in a series of hostilities known as the Lapland War and even some of the material evidence on the former close relationships has been reinterpreted in a nationalistic light (Hall 2001; Delle 2008, 64-65; Moshenska 2010; Ylimaunu et al. 2013, 527, 532-533; Seitsonen 2018).

On the other hand, the past quarter of the century has witnessed the fall of the Soviet Union with its satellites. This means that monuments like the memorial of Taavetti Lukkarinen are not currently in focus, but recent developments in international politics - the trade ban on Russia imposed by the USA and the European Union in particular - might lead to their reactivation to serve nationalistic agendas.

Apart from this wider context, the memorial also had many personal meanings. The place and stories connected to it were part of the life histories of people, thus making the execution site an important part of one's life history, identity, and topobiography (for the last, see Karjalainen 2004, 2006). The tree memorial of Taavetti Lukkarinen is a place of memories that has shaped many life histories. The sorrow and guilt that resulted from the death of Lukkarinen cast its shadow even on 
the generations unborn at the time of the execution; material culture can create memories of things and events that were not witnessed in person or that did not take place at all (Garattini 2007). On the other hand, continual remembrance at designated places can help to recover or heal from tragic events (Tota 2005; Seitsonen and Koskinen-Koivisto 2018). Hence, memories that are building blocks of our life histories do not necessarily need to consist of events witnessed first-hand. Neither is the authenticity of the place necessary to the creation of personal memories.

Memories are linked to material objects that acquire meanings through embodied actions. The hanging site became the place to remember the event partially through a process where people gave meaning to the place by carving crosses onto the trees. This act could be seen within a similar framework to the contemporary habit of raising spontaneous memorials in order for society to cope, channel and negotiate traumatic events (Milošević 2018, 53). Material culture and embodied practices are thus crucial in producing and sustaining memories (Hallam and Hockey 2001; Seitsonen and Koskinen-Koivisto 2018). Beckstead et al. (2011) have explicitly stated that even the selection of the materials used in the creation of memorials impart meaning and significance; the use of long-lasting materials - here iron and granite - forcefully conveys the social necessity of remembering. The restoration and reparation of these monuments is work done to prevent forgetting. In the case of the hanging tree memorial, one of the interviewees had made a special effort to clean the site and to make people remember Taavetti Lukkarinen.

Although most visitors knew that the memorial did not mark the site of the actual hanging, the place still raised strong feelings. Something is usually considered true if the story is based on a first-hand witness account, but people tend to forget things, manipulate things, and choose what to tell. Especially when recollecting unpleasant, dreadful memories, people may unconsciously falsify them to make the event more tolerable (Heimo 2010, 57-58; Cole 2015). Similar to what Burström (2009a) noticed when interviewing people at an archaeological excavation of a Second World War refugee camp, the things people remembered at the tree memorial did not always coincide with 
archaeological finds or what could be deduced from written sources. People had strong visual images of how the place had looked in the past, and these images had little to do with the actual topography of the site. Although the authenticity of the place was not necessary for the creation of memories, for some of the interviewees, it seemed to be important to know the exact location of the original hanging tree (I6 2014; I8 2014; I13 2014). Long debates ensued and participants compared maps to find out where the tree had been; in many cases, it was arguably more important for people to reflect their memories correctly than to precisely locate the last moments of Taavetti Lukkarinen. As memories of place form an important part in the construction of one's identity, it may be hard to admit to not remembering something correctly.

Archaeology can help - maybe not to reveal the hopes, motivations and fears of the victim but at least to paint a fuller picture of his last moments (Ikäheimo et al. in press). As Layla Renshaw (2011) has noted, systematic investigation of the traumatic past can serve to allay anxieties around memory and forgetting. Archaeology can unearth forgotten histories and provide closure, and help people to close a painful episode (cf. Gonzalez-Ruibal 2007, 216). As the centennial of Taavetti Lukkarinen's execution occurred in late 2016, it also seems that his dramatic death needed to be raised once more into discussion as archaeological excavations at the tree memorial had a clear impact on the public and the participation of archaeologists in the commemoration mattered (I2 Lukkarinen 2014).

The project received attention both in printed and social media, where several bloggers wrote about Lukkarinen after the excavations. The Facebook group set up to inform those who were interested to learn more about the project (https://www.facebook.com/groups/hirttopuu/) actually brought some relatives of Lukkarinen's together. The public also approached the researchers with requests to give lectures and to participate in integrating the surroundings of the memorial into the new main entrance of the Oulu University of Applied Sciences. In fact, with scholarly attention paid 
to the memorial and Taavetti Lukkarinen's hanging, the local society better understood and appreciated the somewhat tormented past in the present.

\section{Conclusions}

The interviews conducted during the excavations of the hanging tree memorial highlight the multiple meanings given to the site. Although the question regarding the actual location of the hanging tree raised strong feelings in some of the interviewees, in the end the authenticity of the place was not a prerequisite for its importance. The story of Taavetti Lukkarinen has been used simultaneously both for nationalistic purposes and for building individual family histories. At the same time, this story has been lost for most of the people living in Oulu and the hanging tree has become an urban legend and the memorial a place for mundane activities from school and skiing trips to drinking and gambling. The archaeological fieldwork that coincided roughly with the time of the centennial of Lukkarinen's death raised awareness about his story and on an individual level helped the family members to negotiate with their family past. According to one interviewee we had highlighted the story of Taavetti Lukkarinen with actions defined by her as 'purifying work that eases the tragedies of generations' (I2 Lukkarinen 2014).

\section{Acknowledgements}

We wish to thank all the informants who shared their memories concerning the hanging tree memorial of Taavetti Lukkarinen. We are also grateful for the members of the staff of Oulu University of Applied Sciences who showed their interest in the memorial and our research. And, finally, we would like to express our sincere gratitude to the editors of Journal of Community Archaeology and Heritage and to its anonymous reviewers, whose constructive comments and suggestions improved our contribution significantly. 


\section{References}

Interviews

I1 2014: face-to-face interview.

I2 Lukkarinen 2014: phone interview between Marianne Lukkarinen and Äikäs, 12 August 2014.

I3 2014: phone interview by Äikäs, 12 August 2014.

I5 Karhumaa 2014: interview of Jorma Karhumaa, first lieutenant, retired, 19 August 2014.

I6 2014: face-to-face interview.

I7 2014: face-to-face interview.

I8 2014: face-to-face interview.

I11 2014: face-to-face interview.

I12 2014: face-to-face interview.

I13 2014: face-to-face interview.

I14 2014: face-to-face interview.

I17 Pasanen 2014: e-mail interview between Antti Pasanen and Äikäs, 14 and 18 September 2014.

I18 2014: e-mail to Äikäs 18 September 2014.

I19 2014: e-mail to Äikäs and phone interview by Äikäs, 10 August 2015.

I20 2014: face-to-face interview. 


\section{Literature}

Beckstead, Zachary, Gabriel Twose, Emily Levesque-Gottlieb, and Julia Rizzo. 2011. “Collective remembering through the materiality and organization of war memorials." Journal of Material Culture 16(2): 193-213.DOI: 10.1177/1359183511401494

Brewer, John. 2006. "Memory, truth and victimhood in post-trauma societies." In The Sage Handbook of Nations and Nationalism, edited by Gerard Delanty and Krishan Kumar, 214-224. London: Sage Publications.

Burström, Mats. 2009a. "Selective remembrance: Memories of a Second World War refugee camp in Sweden.” Norwegian Archaeological Review 42(2): 159-172.

Burström, Mats. 2009b. "Garbage or heritage: The existential dimension of a car cemetery.” In Contemporary Archaeologies: Excavating Now, edited by Cornelius Holtorf and Angela Piccini, 131-143. Frankfurt am Main: Peter Lang.

Burström, Mats, Tomás Diez Acosta, Estrella González Noriega, Anders Gustafsson, Ismael Hernández, Håkan Karlsson, Jesús M. Pajón, Jesús Rafael Robaina Jaramillo, and Bengt Westergaard. 2009. "Memories of world crisis. The archaeology of a former Soviet nuclear missile site in Cuba." Journal of Social Archaeology 9(3): 295-318. DOI: 10.1177/1469605309337884. Cameron, Emilie. 2008. "Indigenous spectrality and the politics of postcolonial ghost stories." Cultural Geographies 15: 383-393. DOI: 10.1177/1474474008091334

Clarke, David, Anna Cento Bull, and Marianna Deganutti. 2017. "Soft power and dark heritage: Multiple potentials.” International Journal of Cultural Policy 23(6): 660-674.

Cole, Tim. 2015. “(Re)Placing the past: Spatial strategies of retelling difficult stories.” Oral History 42 (1): $30-49$. 
Delle, James A. 2008. “A tale of two tunnels. Memory, archaeology, and the Underground Railroad.” Journal of Social Archaeology 8(1): 63-93. DOI: 10.1177/1469605307086078

Díaz-Andreau, Margarita and Timothy Champion, editors. 1996. Nationalism and Archaeology in Europe. New York: Routledge.

Dimitrovski, Darko, Vladimir Senić, Dražen Marić, and Veljko Marinković. 2017.

"Commemorative events at destination memorials - a dark (heritage) tourism context."

International Journal of Heritage Studies 23(8): 695-708. DOI: 10.1080/13527258.2017.1317645.

Edelman, Murray. 1995. From Art to Politics: How Artistic Creations Shape Political Conceptions.

Chicago - London: University of Chicago Press.

Enbuske, Matti. 2013. ’Pekka Vesaisen historia: myyttinen sissipäällikkö, kovaluonteinen talonpoika 1500-luvulta." Faravid 37: 35-57.

Fewster, Derek. 2006. Visions of Past Glory: Nationalism and the Construction of Early Finnish History. Helsinki: Finnish Literature Society.

Garattini, Chiara. 2007. "Creating memories: Material culture and infantile death in contemporary Ireland.” Mortality 12(2): 193-206. DOI: 10.1080/13576270701255172.

González-Ruibal, Alfredo. 2007. "Making things public: Archaeologies of the Spanish Civil War." Public Archaeology 6(4):203-226. DOI: 10.1179/175355307X264165.

Hall, Martin. 2001. "Social archaeology and the theatres of memory." Journal of Social Archaeology 1(1): 50-61. DOI: 10.1177/146960530100100104.

Hallam, Elizabeth and Hockey, Jenny. 2001. Death, memory and material culture. Oxford: Berg. 
Hautala-Hirvioja, Tuija Helena. 2015. "Reflections of the past: A meeting between Sámi cultural heritage and contemporary Finnish Sámi." In Relate North: Art, Heritage \& Identity, edited by Timo Jokela and Glen Coutts, 78-97. Rovaniemi: Lapland University Press.

Heimo, Anne and Ulla-Maija Peltonen. 2003. "Memories and histories, public and private: After the Finnish Civil War." In Memory, History, Nation. Contested Pasts, edited by Katharina Hodgkin and Susannah Radstone, 42-56. New York: Routledge.

Heimo, Anne. 2010. Kapina Sammatissa. Vuoden 1918 paikalliset tulkinnat osana historian yhteiskunnallisen rakentamisen prosessia. Helsinki: Suomalaisen Kirjallisuuden Seura.

Herva, Vesa-Pekka. 2014. "Haunting heritage in an enchanted land: Magic, materiality and Second World War German material heritage in Finnish Lapland.” Journal of Contemporary Archaeology 1(2): 297-321.DOI: 10.1558/jca.v1i2.18639.

Ikäheimo, Janne, Tiina Äikäs, and Titta Kallio-Seppä in press. ”Memorialization and heritagization: Investigating the site of the last execution by hanging in Finland."Historical Archaeology.

Ikäheimo, Janne, Tiina Kuvaja and Tiina Äikäs 2016. 'The ghost of Taavetti Lukkarinen and the haunting legacy of a 1916 hanging site." Time \& Mind: The Journal of Archaeology, Consciousness and Culture 9(4): 315-333. DOI: 10.1080/1751696X.2016.1244950.

Kaleva 1935

Karjalainen, Pauli Tapani. 2004. ”Ympäristö ulkoa ja sisältä: Geografiasta geobiografiaan.” In Paikan heijastuksia. Ihmisen ympäristösuhteen tutkimus ja representaation käsite, edited by Raine Mäntysalo, 49-68. Jyväskylä: Atena kustannus.

Karjalainen, Pauli Tapani. 2006. "Topobiografinen paikan tulkinta.” In Paikka: Eletty, kuviteltu, kerrottu, edited by Seppo Knuuttila, Pekka Laaksonen, and Ulla Piela, 83-92. Helsinki:

Suomalaisen Kirjallisuuden Seura. 
Kivimäki, Ville. 2012. "Between defeat and victory: Finnish memory culture of the Second World War." Scandinavian Journal of History 37(4): 482-504. DOI: 10.1080/03468755.2012.680178.

Kohl, Philip L. and Clare P. Fawcett. 1995. Nationalism, Politics, and the Practice of Archaeology. Cambridge: Cambridge University Press.

Kohl, Philip L. 1998. "Nationalism and archaeology: On the construction of nations and the reconstructions of the remote past.” Annual Review of Anthropology, 27: 223-46. DOI: 10.1146/annurev.anthro.27.1.223.

Lackman, Matti. 2012. Sotavankien pako Muurmannin ratatyömaalta 1915-1918. Historiallisia tutkimuksia 261. Helsinki: Suomalaisen Kirjallisuuden Seura.

Logan, William and Keir Reeves.2009. "Introduction.” In Places of Pain and Shame: Dealing with 'difficult heritage', edited by William Logan and Keir Reeves, 1-14. London - New York: Routledge.

Manninen, E. N. 1939. Unkka Manni. Lapin mies sotatiellä. Jyväskylä: Gummerus.

Milošević, Ana 2018. "Historicizing the present: Brussels attacks and heritagization of spontaneous memorials." International Journal of Heritage Studies 24(1): 53-65.

Moshenska, Gabriel. 2010. "Charred churches or iron harvests? Counter-monumentality and the commemoration of the London Blitz.” Journal of Social Archaeology 10(1): 5-27. DOI: $10.1177 / 1469605309353122$.

Núñez, Milton. 2011. “Archaeology and the creation of Finland's national identity.” In Archaeology and Indigenous Peoples in the North, edited by A. Olofsson, 93-118. Archaeology and Environment 27. Umeå: Umeå University.

Oinas, Outi. 2008. Kauniit asiat ja ihmisten ilot eivät voi olla Jumalalle vieraita. Kirjailija, pappi Arvi Järventaus ja Lappi. Acta Universitatis Lapponiensis 155. Rovaniemi: Lapin yliopisto. 
Pentzin, Leino. 1943. ”Synkkiä muistoja taistelun tieltä.” Sotavanhus 1943: 77-78.

Raivo, Petri. 2000. “"This is where they fought.' Finnish War landscapes as a national heritage.” In The Politics of War Memory and Commemoration, edited by Timothy G. Ashplant, Graham Dawson, and Michael Roper, 145-164. London: Routledge.

Renshaw, Layla. 2011. Exhuming loss: Memory, materiality and mass graves of the Spanish Civil War. Walnut Creek, CA: Left Coast Press.

Schofield, John, William Gray Johnson, and Colleen M. Beck. 2002. "Introduction: Matériel culture in the Modern World." In Matériel Culture: The Archaeology of Twentieth Century Conflict. One World Archaeology 44, edited by John Schofield, William Gray Johnson, and Colleen M. Beck, 18. London - New York: Routledge.

Seitsonen, Oula. 2018. Digging Hitler's Arctic War. Archaeologies and Heritage of the Second World War German Military Presence in Finnish Lapland. Doctoral dissertation, University of Helsinki.

Seitsonen, Oula and Eerika Koskinen-Koivisto. 2018."'Where the F... is Vuotso?': heritage of Second World War forced movement and destruction in a Sámi reindeer herding community in Finnish Lapland.” International Journal of Heritage Studies 24(4): 421-441.

Silvander, C.-E. 2005. “Spöken, märkliga stenar ochen hemlig tunnel.” Vikingen: Svenska privatskolan i Uleåborg 2005: 4-5.

Skiftesvik, Joni. 1987. Isäni, sankari. Porvoo: WSOY.

Smith-Solbakken, Marie and Hans-Jørgen Wallin Weihe. 2012. "Preserving the past and intervening in the future through memorials and gravestones." In Painful Pasts and Useful Memories: Remembering and Forgetting in Europe, edited by Barbara Törnquist-Plewa and Niklas Bernsand, 193-206. CFE Conference Papers Series 5. Centre for European Studies, Lund. 
Stone, Philip. 2006. "A dark tourism spectrum: Towards a typology of death and macabre related tourist sites, attractions and exhibitions." Tourism: An Interdisciplinary International Journal 54(2): 145-160.

Tota, Anna Lisa. 2005. “Terrorism and collective memories: Comparing Bologna, Naples and Madrid 11 March.” International Journal of Comparative Sociology 46(1-2): 55-78. DOI: $10.1177 / 0020715205054470$.

Trigger, Bruce G. 1995. "Romanticism, nationalism, and archaeology.” In Nationalism, Politics, and the Practice of Archaeology, edited by Philip L. Kohl and Clare P. Fawcett, 263-279. Cambridge: Cambridge University Press.

van der Auwera, Sigrid. 2012. "Contemporary conflict, nationalism, and the destruction of cultural property during armed conflict: A theoretical framework." Journal of Conflict Archaeology 7(1): 49-65. DOI: 10.1179/157407812X13245464933821.

Wegelius, K. A. 1924. Aseveljet I: läntinen etappi ja Simon kahakka. Porvoo: Werner Söderström Osakeyhtiö.

Winter, Jay and Emmanuel Sivan. 2000. "Setting Framework." In War and Remembrance in the Twentieth Century, edited by Jay Winter and Emmanuel Sivan, 6-39.Cambridge: Cambridge University Press.

Ylimaunu, Timo, Paul R. Mullins, James Symonds, Titta Kallio-Seppä, Hilkka Heikkilä, Markku Kuorilehto, and Siiri Tolonen. 2013. "Memory of barracks: World War II German 'Little Berlins' and post-war urbanization in Northern Finnish towns." Scandinavian Journal of History 38(4): 525-548. DOI: 10.1080/03468755.2013.822457. 
${ }^{i}$ See http://www.tenk.fi/sites/tenk.fi/files/HTK_ohje_2012.pdf.

ii ii Altogether three dates have been put forward as the execution date: 2, 3 and 6 October 1916. The inscription on the handrail gives the date as 6.x.1916, while 3.x.1916 is the date carved on his gravestone. The documents of the Oulu County Prison stored at the Oulu Provincial Archive state explicitly that Lukkarinen was handed over to the Russian authorities in the early hours of 3 October 1916.

iii The day was Sunday, while the exact anniversary should have been celebrated on Thursday, 3 October 1935. A weekday was probably avoided for practical reasons and this resulted in the misconception regarding the exact hanging date now documented in the restored copper handrail cover of the tree memorial. 